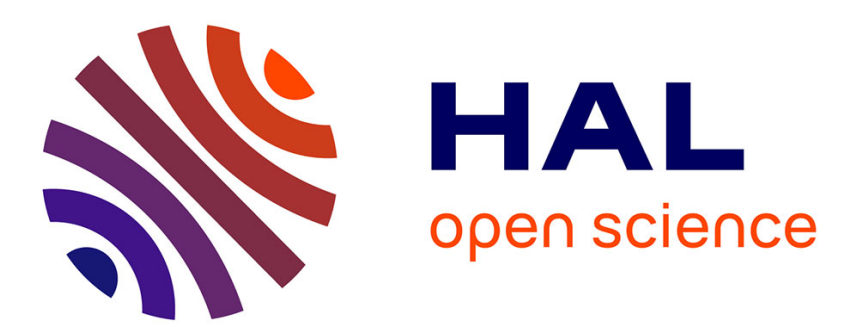

\title{
Experimental determination of the lateral spreading velocity of an electron-hole plasma confined in a $\mathbf{P}+\nu$ $\mathrm{P}+$ structure
}

\author{
J.P. Chante, J.J. Urgell
}

\section{To cite this version:}

J.P. Chante, J.J. Urgell. Experimental determination of the lateral spreading velocity of an electronhole plasma confined in a $\mathrm{P}+\nu \mathrm{P}+$ structure. Journal de Physique Lettres, 1976, 37 (10), pp.243-245. 10.1051/jphyslet:019760037010024300 . jpa-00231284

HAL Id: jpa-00231284

https://hal.science/jpa-00231284

Submitted on 1 Jan 1976

HAL is a multi-disciplinary open access archive for the deposit and dissemination of scientific research documents, whether they are published or not. The documents may come from teaching and research institutions in France or abroad, or from public or private research centers.
L'archive ouverte pluridisciplinaire HAL, est destinée au dépôt et à la diffusion de documents scientifiques de niveau recherche, publiés ou non, émanant des établissements d'enseignement et de recherche français ou étrangers, des laboratoires publics ou privés. 


\title{
EXPERIMENTAL DETERMINATION OF THE LATERAL SPREADING VELOCITY OF AN ELECTRON-HOLE PLASMA CONFINED IN A $\mathbf{P}^{+} v \mathrm{P}^{+}$STRUCTURE
}

\author{
J. P. CHANTE and J. J. URGELL
}

Laboratoire d'Electronique Automatique et Mesures Electriques, Ecole Centrale de Lyon, B.P. 163, 69130 Ecully, France

(Reçu le 26 avril 1976, accepté le 5 juillet 1976)

\begin{abstract}
Résumé. - Nous proposons une méthode utilisant un triac pour mesurer la vitesse d'étalement d'un plasma situé dans la couche $v$. Pour une couche $v$ dont l'épaisseur est de $150 \mu \mathrm{m}$ cette vitesse est de $100 \mu \mathrm{m} / \mu \mathrm{s}$.

Abstract. - A method is proposed, using a triac like structure, to measure the spreading velocity of the plasma in the $v$ layer. For a $v$ layer width of $150 \mu \mathrm{m}$ the spreading velocity is found to be equal to $100 \mu \mathrm{m} / \mu \mathrm{s}$.
\end{abstract}

Bidimensional current flow in semiconductor devices has received considerable interest during the last few years and a certain number of papers have analysed bidimensional problems associated with transistors [1, 2].

For power devices the conduction area is obviously large and the unidimensional models are a very crude approximation of the actual behaviour. Some papers [3, 4] devoted to the analysis of the turn-on of thyristors have described the spreading of the conduction area during the turn-on.

This note presents a new experimental approach aimed to measure the spreading velocity of an electronhole plasma appearing in some part of the $v$ layer of a $\mathrm{P}^{+} v \mathrm{P}^{+}$sandwich (Fig. 1a).

For this measurement, two $\mathrm{N}^{++}$on $\mathrm{P}^{+}$regions have been diffused and the two faces have been covered by an ohmic contact (Fig. 1b). This enables

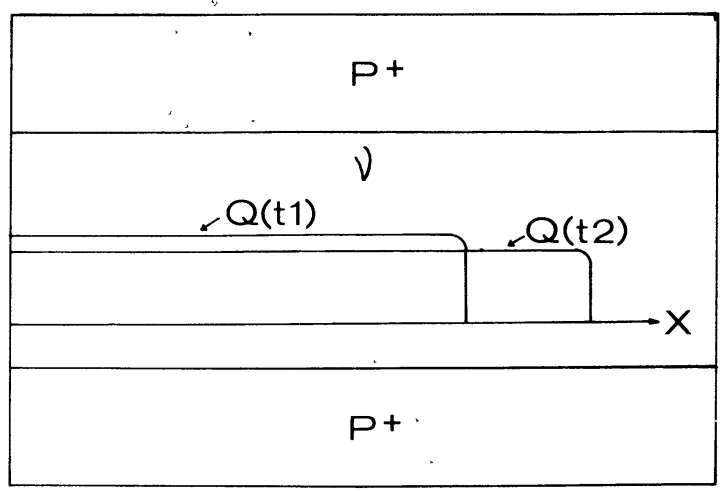

Fig. 1a. $-\mathrm{P}^{+} v \ddot{\mathrm{P}^{+}}$structure under test. We see in the $v$ layer the plasma spreading at $t=t_{1}$ and $t=t_{2}, t_{2}>t_{1}$.

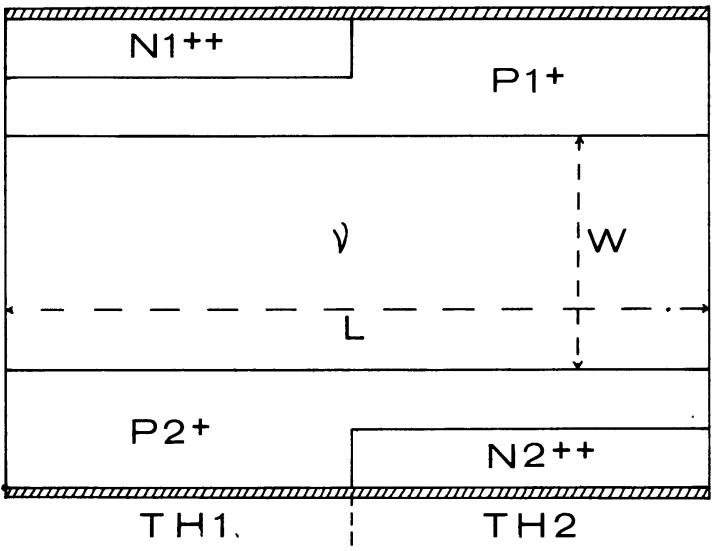

Fig. 1b. - Triac like device used to test the $\mathrm{P}^{+} v \mathrm{P}^{+}$structure $W=150 \mu \mathrm{m}, L=2 \mathrm{~mm}$.

one to realize a triac like structure composed of the thyristors $\mathrm{TH}_{1}$ and $\mathrm{TH}_{2}$.

The general idea of the method is to use the conduction of $\mathrm{TH}_{1}$ to create a plasma in the $v$ region under $\mathrm{N}_{1}^{++}$and the charge-controlled triggering of $\mathrm{TH}_{2}$ to detect the charge transfer in the $v$ region from $\mathrm{TH}_{1}$ to $\mathrm{TH}_{2}$.

Let us now describe the experimental steps :

(i) $\mathrm{TH}_{1}$ is turned on in order to create the plasma under $\mathrm{N}_{1}^{++}$. As long as $\mathrm{TH}_{1}$ is conducting, the ohmic contact overlapping $\mathrm{N}_{1}^{++}$and $\mathrm{P}_{1}^{+}$maintains the plasma under $\mathrm{N}_{1}^{++}$since the transistor $\mathrm{N}_{1}^{++} \mathrm{P}_{1}^{+} v$ is saturated and the potential of the $v$ region is close to the potential of the $\mathrm{P}_{1}^{+}$surface under $\mathrm{N}_{2}^{++}$

(ii) The current through $\mathrm{TH}_{1}$ is driven to zero controlling $\mathrm{d} I / \mathrm{d} t$ (Fig. 2a) and after a delay time $t_{\mathrm{d}}$ 


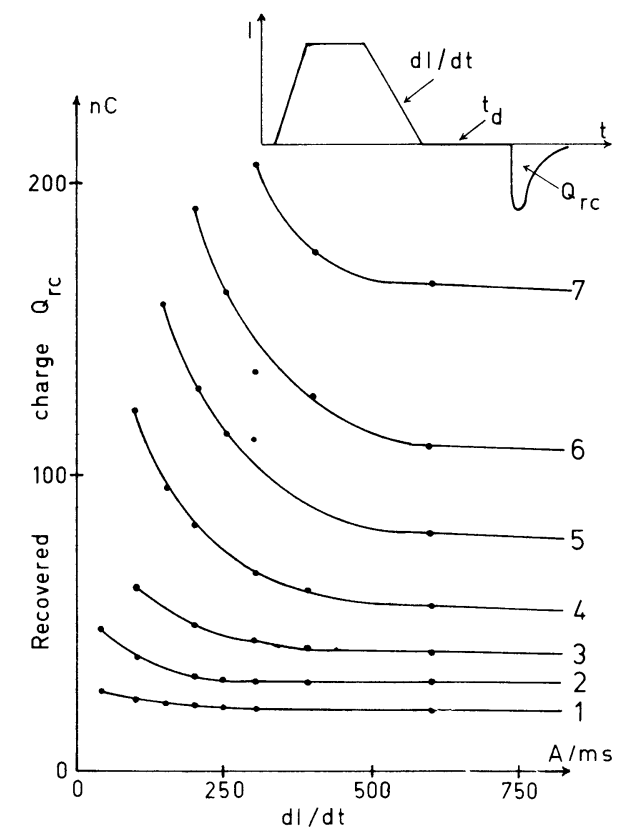

FIG. $2 a$. - Recovered charge $Q_{\mathrm{RC}}$ at the triggering onset of $\mathrm{TH}_{2}$ versus $\mathrm{d} I / \mathrm{d} t$ for several temperatures : 1) $\theta=100^{\circ} \mathrm{C}$; 2) $\theta=80^{\circ} \mathrm{C}$; 3) $\theta=60^{\circ} \mathrm{C}$; 4) $\theta=40^{\circ} \mathrm{C}$; 5) $\theta=20^{\circ} \mathrm{C}$; 6) $\theta=0^{\circ} \mathrm{C}$; 7) $\theta=-20^{\circ} \mathrm{C}$.

a fast rising reverse voltage is applied to the device. The amplitude of this voltage is small enough to prevent a regular $\mathrm{d} v / \mathrm{d} t$ switching of $\mathrm{TH}_{2}$. The delay $t_{\mathrm{d}}$ is adjusted so that the recovery of the corresponding charge $Q_{\mathrm{R}}$ corresponds to the onset of the triggering of $\mathrm{TH}_{2}$. This delay is called $t_{\mathrm{dc}}$ and the corresponding charge $Q_{\mathrm{RC}}$. If $t_{\mathrm{d}}<t_{\mathrm{dc}}$ the charge $Q_{\mathrm{R}}$ is greater than $Q_{\mathrm{RC}}$ and $\mathrm{TH}_{2}$ is turned on, if $t_{\mathrm{d}}>t_{\mathrm{dc}}$ then $Q_{\mathrm{R}}<Q_{\mathrm{RC}}$ and $\mathrm{TH}_{2}$ remains off.

Figure $2 a$ shows, for several temperatures, this critical recovered charge $Q_{\mathrm{RC}}$ as a function of $\mathrm{d} I / \mathrm{d} t$.

The charge $Q_{\mathrm{RC}}$ is recovered maintaining a voltage between the two electrodes. As a consequence :

(i) the recovery conditions correspond to the presence of an electric field in the $v$ region as described by $H$. Benda and E. Spenke [5] ;

(ii) the recovery time is short enough to prevent, during the recovery, the action of the transistors $\mathrm{N}_{2}^{++} \mathrm{P}_{2} v$ and $\mathrm{P}_{1}^{+} v \mathrm{P}_{2}^{+}$on the measured value of $Q_{\mathrm{RC}}$.

For high values of $\mathrm{d} I / \mathrm{d} t$ a large concentration of plasma exists under $\mathbf{T H}_{1}$ when the current goes to zero, $t_{\mathrm{dc}}$ has to be increased and $Q_{\mathrm{RC}}$ tends towards a constant value (on the right part of figure $2 a$ ). This constant value of $Q_{\mathrm{RC}}$ is noted $2 Q_{\mathrm{C}}$. Indeed when $t_{\mathrm{dc}}$ is large enough, the concentration of the plasma is uniform along the $v$ region, and half of the total area being occupied by $\mathrm{TH}_{1}$ or $\mathrm{TH}_{2}, Q_{\mathrm{RC}}$ corresponds to twice the minimum triggering charge of $\mathrm{TH}_{2}$ which is $Q_{\mathrm{c}}$.

As $\mathrm{d} I / \mathrm{d} t$ is decreased, $t_{\mathrm{d}}$ decreases and $Q_{\mathrm{RC}}$ increases, this can be explained considering that the charge $Q_{\mathrm{C}}$ has to be present under $\mathrm{N}_{2}^{++}$to trigger $\mathrm{TH}_{2}$ and $t_{\mathrm{dc}}$ is too small to have a complete spreading of the charge along the $v$ layer.

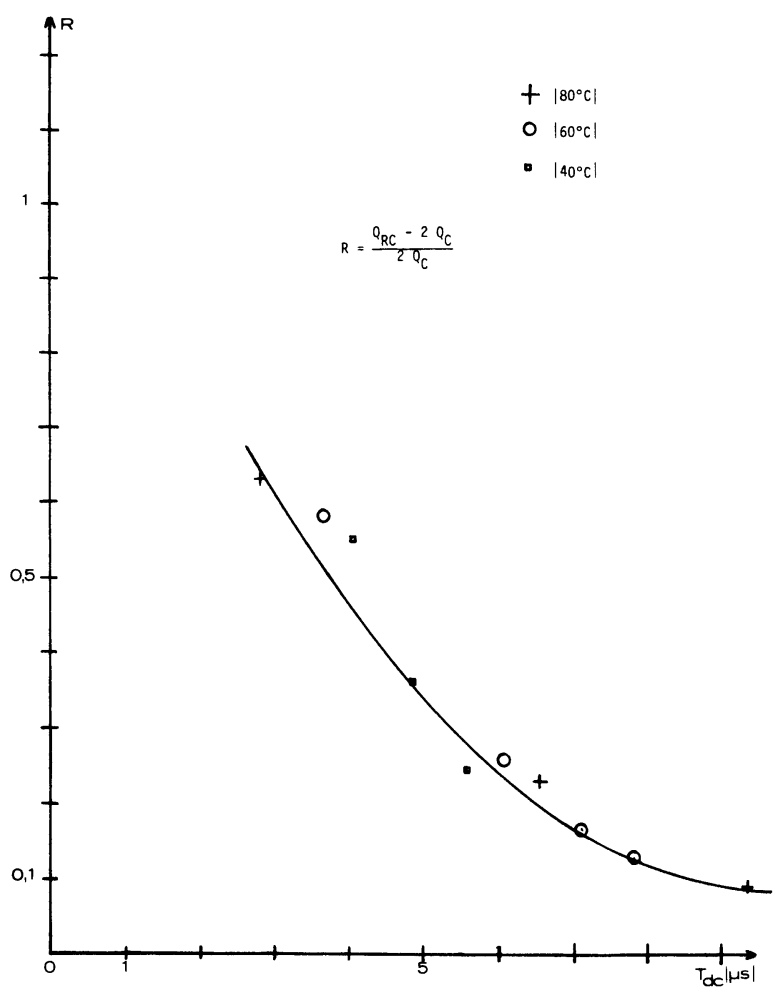

FIG. $2 b .-R=\frac{Q_{\mathrm{RC}}-2 Q_{\mathrm{C}}}{2 Q_{\mathrm{C}}}$ versus the delay time $t_{\mathrm{d}}$.

The ratio :

$$
R\left(t_{\mathrm{dc}}\right)=\frac{Q_{\mathrm{RC}}-2 Q_{\mathrm{C}}}{2 Q_{\mathrm{C}}}
$$

can be computed from the graphs of figure $2 a$ for several temperatures. This ratio is drawn on figure $2 b$ as a function of $t_{\mathrm{dc}}$.

Now, if $Q_{1}$ is the stored charge under $\mathrm{TH}_{1}$ and $Q_{2}$ the stored charge under $\mathrm{TH}_{2}$, it is easy, from $R\left(t_{\mathrm{dc}}\right)$, to derive the ratio $Q_{1} / Q_{2}$ of the charges under $\mathrm{TH}_{1}$ and $\mathrm{TH}_{2}$. We have :

$$
\frac{Q_{1}}{Q_{2}}=1+2 R .
$$

When $t_{\mathrm{dc}}$ is very long $Q_{\mathrm{RC}}=2 Q_{\mathrm{c}}$ and $R\left(t_{\mathrm{dc}}\right)=0$. This means the plasma is uniform along the $v$ layer and $Q_{1}=Q_{2}$. If $t_{\mathrm{dc}}$ is short, $R$ is large and $Q_{1}$ is larger than $Q_{2}$, this means that we have not a complete spreading of the charge in the $v$ layer. The ratio $Q_{1} / Q_{2}$ therefore gives the position of the plasma under the electrodes : for instance : $t_{\mathrm{dc}}=7 \mu \mathrm{s} ; R=0.2$; $Q_{1} / Q_{2}=1.4$ and the plasma covers $70 \%$ of the area of $\mathrm{TH}_{2}$, that is a length $x=700 \mu \mathrm{m}$ in the $\mathrm{TH}_{2}$ thyristor. The deduced lateral spreading velocity of $100 \mu \mathrm{m} / \mu \mathrm{s}$ is typical of the sandwich $\mathrm{P}^{+} v \mathrm{P}^{+}$tested :

- width of the $v$ layer : $150 \mu \mathrm{m}$,

— resistivity : $30 \Omega . \mathrm{cm}$.

This measured velocity is in agreement with other experimental data $[3,4]$. We believe that this velocity is not due only to diffusion because : 
(i) the diffusion velocity is lower than the measured velocity,

(ii) the diffusion length is about $200 \mu \mathrm{m}$ in the $v$ layer and in that case the diffusion mechanism alone cannot explain the presence of a significant amount of charge at a distance $x=700 \mu \mathrm{m}$.

We suppose that the diffusion of carriers biases the $\mathrm{P}^{+} v$ junctions in the forward direction and the regular diffusion mechanism is accelerated by this injection process.

We are currently working on other $\mathrm{P}^{+} v \mathrm{P}^{+}$sandwiches varying the width of the $v$ layer in order to give a theoretical representation of the spreading velocity.

\section{References}

[1] HAUSER, J. R., IEEE Trans. Electron Devices, ED. 11 (1964) 238.

[2] REY, G. et LETURCQ, P., Etude approfondie du transistor bipolaire (Masson) 1972.

[3] RuHL, H. J., IEEE Trans. Electron Devices, ED. 17 (1970) 672.

[4] Grekhov, I. V., Levinsktein, M. E. and Sergeev, V. G., Soviet Physics-Semicond. 4 (1971) 1844.

[5] Benda, H. and Spenke, E., Proc. IEEE, 55 (1967) 1331. 